\title{
UNIVERSITYOF
}

FORWARD

THINKING

WESTMINSTER用

WestminsterResearch

http://www.westminster.ac.uk/westminsterresearch

Paying for parks. Ticketed events and the commercialisation of public space

Smith, A.

This is an accepted manuscript of an article published by Taylor \& Francis in Leisure Studies, doi: 10.1080/02614367.2018.1497077.

The final definitive version is available online:

https://dx.doi.org/10.1080/02614367.2018.1497077

(C) 2018 Taylor \& Francis

The WestminsterResearch online digital archive at the University of Westminster aims to make the research output of the University available to a wider audience. Copyright and Moral Rights remain with the authors and/or copyright owners.

Whilst further distribution of specific materials from within this archive is forbidden, you may freely distribute the URL of WestminsterResearch: ((http://westminsterresearch.wmin.ac.uk/)).

In case of abuse or copyright appearing without permission e-mail repository@westminster.ac.uk 


\title{
Paying for parks. Ticketed events and the commercialisation of public space
}

\begin{abstract}
Music festivals, sport events, funfairs, exhibitions and other ticketed events provide a source of income for authorities struggling to pay for parks. Park events are also justified as ways of making city parks more exciting and attracting a more diverse range of park users. However, commercial events are often contested as they restrict the availability of public space, and compromise the status of parks as accessible, 'open spaces' that are free to use. These issues are explored here by analysing Battersea Park in London which has a long track record of hosting ticketed events: including the Festival of Britain Pleasure Gardens and, more recently, Formula E motor races. Historical and contemporary analysis of Battersea Park demonstrates how ticketed events privatise park space, providing precedents for future commercialisation and development. The case study also suggests that the growing pressure to transform parks into event venues is changing the ways our parks are governed and managed. This suggests a process of neoliberalisation is occurring, but the research presented here suggests this explanation perhaps oversimplifies the nuances of park commercialisation. Ultimately, the paper highlights the conflicts and issues that arise when the exchange value of public parks is prioritised over their use value.
\end{abstract}

Key words: Parks, funding, events, public space, privatisation, commercialisation 


\section{Paying for parks? Ticketed events and the commercialisation of public space}

\section{Introduction}

City parks provide important recreational spaces for citizens and their status as public goods has spared them from some of the neoliberal reforms that have affected other public services (Smith, Dempsey and Burton, 2014). But this is changing as parks come under increasing pressure to generate their own income. The "introduction of revenue-generating functions in order that parks be self-sustaining" (Davidson, 2013, p.657) is perhaps the defining characteristic of parks in an age of neoliberal austerity. A new emphasis on commercial revenue generation and cost savings has encouraged a shift away from state-centred governance arrangements. Whilst parks remain ostensibly public, in an era of neoliberal austerity they are increasingly produced as capitalist commodities by private organisations (Cooke, 2007). This has significant implications for the provision, distribution and accessibility of urban parks.

The aim of this paper is to explore the role that ticketed events play in processes of park commercialisation. Several research questions are addressed: how do ticketed events affect the publicness of parks, do events encourage new forms of governance; and how can we best understand the conflicts that arise from the transformation of public parks into public-private venues? A detailed review of one particular case - Battersea Park in London - provides the focus. This example was selected because of its history as a contested site, and because of its recent use as the venue for a new electric car racing series - Formula E. Like other city parks subjected to detailed analysis (e.g. Bryant Park in New York: Madden, 2010; Zukin, 1995; 2010), Battersea Park is a bellwether case that allows researchers to anticipate how other 
parks may develop in the future. This well-known and centrally located park is controlled by Wandsworth Borough Council, the Conservative Party's flagship local authority, so is an exemplar of the way UK parks are changing in an era of neoliberal austerity. The paper examines how neoliberalisation applies to parks management and explores how these processes - usually discussed in the context of US parks - work in the UK.

Research was conducted using a combination of primary and secondary research methods. Key stakeholders involved in UK / London parks were interviewed (The Parks Alliance, Heritage Lottery Fund, London Green Spaces Friends Network, Parks for London, The Open Spaces Society). Key actors involved in the Battersea Park case study (from Wandsworth Council, Enable Leisure \& Culture, Battersea Park Action Group, Formula E, London and Partners) were also interviewed, as were representatives of commercial event interests (the National Outdoor Events Association, CSM Sport and Entertainment). Historical perspective was provided by researching the newspaper archives located at Battersea Library.

The paper begins with a review of key ideas and literatures related to the management and governance of parks. A more specific introduction to the contested role of events in parks is then provided. These sections provide the conceptual foundations for the subsequent account of the role of ticketed events in the commercialisation of Battersea Park; focusing first on the legacies of the Festival of Britain (1951); and The Festival of British Genius (1977) and then on more recent events, including Formula E motor races (2015 and 2016). This longitudinal perspective demonstrates how events monetise and part-privatise park space, providing precedents for future commercialisation and development. Ultimately, the paper highlights the conflicts and issues that arise when the exchange value of public space is prioritised over its use value. 


\section{The commercialisation of parks}

Lasdun (1991, p.187) suggests the idea of a park is losing its universal meaning "as it becomes increasingly appropriated by other enterprises - business parks, individual parks, theme parks, leisure parks and so forth". This view is shared by Zukin (1995, p.261) who asks: "does anyone know in these days of entertainment, security and retail shopping what a park is?" The rise of the entertainment industry has contributed to this confusion through their appropriation of terminology and the installation of commercial attractions in parks. This latter trend has instigated a long running debate about whether parks should be tranquil havens separated from the rest of a city or integrated sites for entertainment. Lasdun (1991) encapsulates the opposing positions in one key question: should parklands or playgrounds be the main priority?

In the UK, many municipal parks were conceived and opened in the 19th century and there are long running debates about how best to manage these historical spaces. In the 1980s and 1990s some felt parks were not being used because they were not well maintained, whereas others felt that they were not satisfying people's needs because they were too old fashioned (Harding, 1999). Influential reports suggested redesigning parks so that they were more relevant to, and better integrated with, modern life (Demos/Comedia, 1995). One key aspect of this debate was how parks could accommodate a growing number of different functions, including "demands for musical performances and sport" (Harding, 1999, p.5). These debates have resurfaced in the $21^{\text {st }}$ Century mainly because of a new series of funding crises.

\section{Governance}


New institutional arrangements have been adopted to manage UK parks, underpinned by a neoliberal approach that strives for "economic efficiency" (Smith et al., 2014). Using de Magalhães and Carmona’s (2009) terminology, there has been a shift from a state-centred model, to market-centred and user-centred models. The latter involves authorities developing partnerships with Friends Groups who take on fund raising and management functions. One advantage of a user-centred model is that management organisations have a "direct interest in the quality of the public spaces and related services primarily for their use value" (de Magalhães and Carmona, 2009, p.125). This shift to volunteerism is typical of neoliberal regimes (Perkins, 2009) and, whilst it may result in citizen empowerment, it is often motivated by cost savings. These outcomes are not necessarily incompatible: Rosol (2010, p.550) suggests that "downloading" responsibility onto community groups "may serve a neoliberal agenda, but at the same time still foster an emancipatory agenda”.

Contracting out park maintenance to private companies is now common practice, and this approach typifies a market-centred model focused on value for money (de Magalhães and Carmona, 2009). Whilst it is still common for local authorities to retain overall management responsibilities and ownership, this is changing as more comprehensive and more complex contracting arrangements are deployed (de Magalhães and Friere Trigo, 2016). In many critical accounts these new arrangements are interpreted as a privatisation of public parks (Cooke, 2007; Zukin, 1995). However, the extent to which parks have been commodified and privatised is contested. The findings of a major European Union funded project suggest that parks have as not been so readily commodified as other public services because of their nature and perception as a public good (Smith et al., 2014). The difficulties converting parks 
into a "chargeable service" has protected them from the negative effects of neo-liberalism, but it has contributed to the relative neglect of established parks (Smith et al., 2014).

In instances where parks are able to generate significant amounts of income, private organisations are often established which allow revenues to be ring-fenced and reinvested in parks. The most famous example is New York's Central Park Conservancy (CPC). In the late 1990s, the relationship between the city and the CPC was transformed into a contractual one, with more onerous functional and financial obligations specified. Cooke (2007) regards this as a form of privatisation, a less democratic form of governance which has implications for how the park is used. For example, it means the space has to be highly controlled - to ensure that "donors feel their investments are well used and protected" (Cooke, 2007, p.127). This limits the types of activities that can take place in Central Park, determining its function and diminishing the "looseness" of the space (Nevarez, 2007).

A more radical way of governing parks is through a version of the Business Improvement District (BID) model where control of a park is devolved to local businesses who can raise revenue to help pay for it. Zukin (1995) famously analysed Bryant Park, New York, where the BID model was applied to gentrify the park and reclaim it from undesirable users. Zukin (1995) regards this as an aggressive form of privatisation, where the publicness of the space was eroded. The BID model also highlights the way in which parks are commodified. At the heart of this model is the notion that parks are important because they add value to adjacent property and improve the profitability of local businesses (Krinsky and Simonet, 2011). One criticism of this approach is that it benefits "destination" parks in privileged locations, rather than encouraging the broader provision of green space. For Millington (2015), it is this process that represents the neoliberalisation of parks. 
Davidson (2013, p.651) highlights two key contested trends currently affecting parks: management by private companies and the introduction of "revenue-generating functions". These characteristics are clearly linked as new governance arrangements are implemented to increase the amount of revenue earned by parks. This explains the rise of entrepreneurial parks and more commercialised spaces which are "a product of the neoliberal prescription that public parks must be financially self-sustaining" (Loughran, 2014, p.62). Commercial revenue is earned through established streams such as parking and licensing, but also through sponsorship. Park authorities have long earned income from concessions (cafes, equipment hire, sports facilities), but in the contemporary era, the companies involved have been given greater control over park space. Perkins (2009) notes how some authorities in the US have leased public parks to coffee chains who assume responsibility for their upkeep. This allows the local state to provide parks, whilst avoiding the costs of maintaining them. Unsurprisingly, this arrangement is opposed by those who see it as "pimping out parks" and the "beginning of privatisation" (Perkins, 2009).

\section{Park events}

Staging commercial events is a very common way of generating revenue from parks;

something that is explored at length in this paper. Parks earn revenue from events by charging organisers for the hire of space, by taking a percentage of revenue earned through ticket sales and / or through income earned through concessions. City parks and commons have always hosted public entertainment such as circuses and fairs, but in the contemporary era parks are used more frequently for more commercially oriented events (Smith, 2016). Zukin (2010, p.128) notes how parks run as BIDS in New York City "raise revenue by renting space in the 
park to private promoters for outdoor product demonstrations, phot shoots and festivals". For example, Bryant Park was used as the hub for New York's Fashion Week for 17 years. These types of events can be regarded as positive ways to animate a park and "broaden its user base" (Zukin, 2010, p.128), but are also vehicles for exclusion, appropriation and commercialisation. They are part of the way in which some parks are transformed into "luxury public spaces that lure tourists and wealthy consumers for leisure and consumption" (Loughran, 2014, p.50). Residents often object to the disruption and environmental impacts they are known to cause (Smith, 2016), but there are ideological objections too - restricting access to ticket holders contradicts the idea of a public park (Smith, 2014).

The most extreme and controversial examples of park events involve the staging of motor races. These feature in several Australian parks, for example the V8 races staged in Sydney Olympic Park (Davidson, 2013) and Adelaide Parklands (Tranter and Lowes, 1999), and the Formula 1 Grand Prix staged in Albert Park, Melbourne. According to Tranter and Lowes (2009, p.20) the "commercialisation of the public open space of Albert Park that occurs through the Grand Prix is symbolic of an ideology that values profit over sustainability". This theme is also explored in Davidson's (2013, p.670) work on Sydney's Olympic Park, where the introduction of V8 races caused "a significant shift in the park's development trajectory" undermining its image as a sustainable site. Lowes' (2002) research on plans for Indy Car racing in Hastings Park, Vancouver is particularly insightful given the fact that campaigners successfully prevented the races from happening. This was achieved by establishing an alternative vision for the park and by appropriating the discourses adopted by race advocates (Lowes, 2002). The case provides a "classic conflict over the appropriation and development of an urban public space" (Lowes, 2002, p.8) albeit one that demonstrates that "market driven urban development forces do not always win" (Lowes, 2002, p.120). 
Park-based motor racing events in Melbourne and Sydney require controversial state subsidies that are justified by wider economic impacts and the role of park events in city marketing. This represents a slightly different dimension of the entrepreneurial park - where a park acts as a vehicle for the wider promotion of the city. Using parks for events helps cities to promote attractive images to external audiences, but this is not always compatible with everyday uses. This is illustrated by Inroy's (2000) account of the development of Garnethill Park in Glasgow. Here, local youths wanted to play football in the park; something resisted by the City Council who saw the space "as a vehicle for the promotion of city wide activities and for international and non-local entertainment" (McInroy, 2000, p.32). This highlights that exploitation of a park's exchange value affects its use value as a local amenity - a source of conflict that is explored further in this paper.

\section{Battersea Park}

Battersea Park is notable for its size, location and historical significance. The Park covers 80 hectares adjacent to the River Thames - making it the largest municipal park in South London (Nice, 1983). Plans for a park here were conceived in the 1840s and Battersea Park was formally opened by Queen Victoria in 1858. Like many other parks conceived in the 19th Century, Battersea Park was constructed for very moral reasons: to regulate behaviour, to provide space for healthy exercise, and to encourage moral conduct. Real estate development was also a significant factor. In the original plans, a third of the site was allocated to new housing which would repay the costs of creating the new park. Costs subsequently escalated and the project was ultimately paid for using government money - generating controversy. In the mid-19th Century, the Government's view was that as "non-profitable undertakings" 
parks should be provided by philanthropists (Chadwick, 1966). As such, the Chancellor of the Exchequer (Disraeli) was strongly opposed to the proposal to construct Battersea Park. These origins remind us that a restricted role for government and private financing were priorities in the liberal era, as well as the neoliberal one.

\section{The Festival of Britain and its legacy}

The role played by Battersea Park during the 1951 Festival of Britain helps to explain the Park's contemporary renown. The Park hosted the Festival Pleasure Gardens - an annex to the main Festival site. This project was opposed by Battersea Borough Council and an Act of Parliament was needed to exclude the public from 38 acres of Battersea Park whilst the site was constructed (Turner, 2011). Lots of very old, very large trees had to be to cut down and this had to be done at night to avoid public outcry (Mitchell, 2003). Post-war austerity and disputes about the amount of public money used to create the main Festival of Britain site meant the project had to be self-financing. As a result the attractions were highly commercialised, installations were paid for by sponsors and the public were required to pay an entrance fee - all precedents for subsequent commercialisation in Battersea Park.

The funfair installed in Battersea Park at this time became an established attraction which was retained until the mid-1970s. Elborough (2016, p.276) suggests there were political and ideological reasons why it was not removed after the event: "When the Tories came to power they bulldozed the Festival of Britain site, but left Battersea Park alone: its commercial deeds evidently posing less of a threat ideologically to the incoming government". This is another reminder that ideologically driven commercialisation and Battersea Park have a long association. The funfair may have disappeared, but one of the commercial attractions 
currently operating in Battersea Park - the Children's Zoo - dates back to the Pleasure Gardens. There are other obvious physical legacies, most obviously the Grand Vista which was retained as a rather incoherent centrepiece. In 1953 London County Council provided funds to reinstate the Park, and various commercial installations were envisaged for the plots vacated. This prompted the Chairman of the Friends of Battersea Park to write a letter to The Times: "Battersea Park was formed for leisure and recreation and should not be used for private gain or profit" (Bull, 1966). Over the next decade local campaigners had to fight off various development proposals, including a Disneyland style theme park project. Subsequent plans for a leisure park were opposed by Labour Councillors using familiar rhetoric: "a park should be a park and not a great big commercial undertaking... what we want in Battersea Park is somewhere you can breathe, somewhere you can kick a football" (Hoadley cited in South London Press, 1980).

\section{Events in Battersea Park}

The Festival of Britain was not the only national event to influence the form and function of Battersea Park. In 1977, The Festival of British Genius was organised in the Park to mark the Queen's Silver Jubilee (and the centenary of John Player cigarette company). This exhibition - which required an entry fee - was staged on the site of the funfair which had recently closed. The project was resisted by the "Battersea Redevelopment Action Group" who expressed concern that "land would be used for a private concern" and that the exhibition, albeit temporary "would determine the layout of the land for the future" (South London Press, 1976). This proved to be prescient as the 2.28 ha 'British Genius Site' is now used as a venue for private events and exhibitions. A "temporary" venue branded Battersea Evolution is constructed here every year, effectively creating an indoor venue in Battersea Park. Every 
two years the Council (re)apply for planning permission to use the site for this purpose and the 2017/8 schedule suggests it will be used for 62 events (lasting from 1 day to 3 weeks) on 278 days of the year (Wandsworth Council, 2017).

From 1965-1986 Battersea Park was controlled by the Greater London Council (GLC) and during this period, various music concerts were staged in the Park including an infamously lewd performance by The Stranglers in 1978. This band was prohibited from performing at other London venues, highlighting the laissez faire regulation of Battersea Park at this time. The notion of Battersea Park as a liminal site and a site of protest was reaffirmed by events organised by the GLC in the mid-1980s. These included a Free Festival in 1984 (staged to commemorate the $150^{\text {th }}$ anniversary of the Tolpuddle Martyrs) and the Jobs for a Change Festival (1985). Both were staged by the Labour Party controlled GLC as a challenge to Thatcher's UK Government (Bianchini, 1987), emphasising Battersea Park politicisation by successive governing bodies seeking to communicate their values.

In the early 1980s, Battersea Park was described as a 'classic example of the run down Victorian park with immense possibilities but hamstrung by low investment, public resistance and low political interest' (Nice, 1983, p.13). The Wandsworth Councillor interviewed provided a particularly scathing review of the Park's condition at this time: "It was in a very moribund state. I mean, there had been a number of rapes. It was not a safe place to go, very overgrown. It was in a bad way”. Responsibility for Battersea Park passed from the control of the GLC to Wandsworth Borough Council (WBC) in 1986. In subsequent years, a series of improvement projects were implemented to improve the condition of the Park. Several large projects were proposed, including a 3,500 capacity theatre (in 1987), and later (in 1991) an IMAX cinema. Park and council officials justified their support for these by citing the need 
for modern and up to date leisure facilities. For example, support for the theatre project was based on the notion that parks should provide entertainment. Similarly, the cinema proposal was linked to the notion that parks tended to attract a narrow range of people, thus new attractions were warranted: "I personally feel we should be making the park more accessible" (WBC Leisure Services and Amenities Chairman, cited in Wandsworth Borough News, 1991a). These aims were also addressed via the provision of more sports facilities, something which Lasdun (1991, p.184) meant the loss of the Park's "reclusive quality".

WBC has long been a flagship local authority for the Conservative Party and when it assumed responsibility for manging Battersea Park it began applying an entrepreneurial philosophy. In 1991 the local paper published an editorial expressing concern about the Park's management: "the council more perhaps than any other in London is driven by a financial imperative" (Wandsworth Borough News, 1991b). That year Battersea Park hosted approximately 99 events (Wandsworth Borough News, 1991b) and these were beginning to interfere with everyday use. Complaints about the number and type of events staged peaked in the late 1990s, when residents became angry about the use of the park "for purely commercial gain" (Wandsworth Borough News, 1998).

By 1998/1999 park events were generating an annual $£ 460,000$ profit for WBC (Wandsworth Borough News, 1999). The Society for the Protection of Battersea Park argued that staging these events was unlawful "because they prevent free access to all of the Park" (Wandsworth Borough News, 2001). As a result, new restrictions were brought linked to the comprehensive restoration funded by the Heritage Lottery Fund (1998-2004) which recommended fewer, more lucrative, events that would cause less damage (Interview with HLF). This approach ensured the park environment was better protected, but it didn't deal with the notion that 
events were inappropriately exclusive. In the updated Events Strategy (2003), pop concerts and events staged on turf were discouraged, and the idea was to confine most events to the British Genius Site. These policies have generally been maintained, although the number of events has risen: by 2016 Battersea Park was staging over 600 events per year (Interview with WBC; Interview with BPAG).

\section{Formula $E$}

In 2014 a new events controversy emerged when Wandsworth Council announced plans to stage Formula E races in Battersea Park every summer for five years. The first races in the park were staged in June 2015 as the climax of the inaugural Formula E season. These events' origins can be traced to the relationship between WBC and the Mayor of London 2008-2016. The Mayor and Formula E were keen to have a race in London and the city's Deputy Mayor of Policy and Planning (formerly Leader of WBC) played a key role in ensuring it came to Wandsworth. Battersea Park was identified as a suitable venue because its fenced perimeters and configuration suited events in general and motor racing events in particular (Interview with Formula E). Transforming the park into a spectacular racetrack suited the place marketing objectives of Wandsworth Council and the Mayor of London, as well as providing a distinctive setting for organisers.

WBC felt the races were suitable for a public park because of Formula E's mission to promote the use of electric cars. But once the plans were announced, opposition from local people began to emerge which coalesced into the Battersea Park Action Group (BPAG). The original planning application acknowledged that 'Neighbours are extremely unhappy with the 
way the Park is slowly being turned over to commerciality' (WBC, 2015). There were also more specific concerns about the suitability of staging motor racing in a Grade II listed park.

Staging the race required various structures to be assembled and disassembled in the Park including 7 kilometres of metal fences mounted on 1,945 concrete blocks (Interview with Formula E). Formula $\mathrm{E}$ was conscious of the impact this had on the park environment: "concrete blocks, fences, it changes the park" (Interview with Formula E). Park access was restricted before, during and after the races, with only a small section (c.10\%) open to the public during the race weekend. Building the track, the stands and the other event structures disrupted the peace and normal functioning of Battersea Park for several weeks. Opponents also voiced concerns about permanent damage to the Parks' natural environment and built heritage. Whilst Formula E insisted their presence was merely temporary, "it's three weeks tops that we're there and then we're gone" (Interview with Formula E), physical changes were made to provide a suitable race track, including newly tarmacked areas. The BPAG feared these would be deliberately retained as they would be useful for hosting film crews and their trailers - a lucrative source of revenue for many London parks. With a nod to Joni Mitchell's famous lyrics, the representative from the BPAG asked "is this a park or a parking lot?" (Interview with BPAG).

Despite major concerns surrounding the 2015 events, and a much more organised opposition campaign, planning permission for a second edition of Formula E racing was approved in February 2016. Undeterred, the BPAG continued to campaign in the run-up to the races by targeting Formula E sponsors and by threatening direct action. WBC dismissed their opponents as a small group of privileged NIMBYists, but the BPAG were persistent and well resourced, and their campaigning seemed to unsettle Formula E officials who were eager that 
their end of season races would go ahead without negative publicity. In Spring 2016, BPAG crowdfunded a legal challenge, but just before this Judicial Review was due to be heard by the High Court, they reached an agreement with Formula E. The company promised there would be no more races in Battersea Park as long as the BPAG ceased their campaigning and allowed the 2016 edition to go ahead without disruption. So the Action Group forced Formula E to change their plans - a rare example of citizens successfully resisting proposals to stage commercial events in public parks.

\section{Formula E as neoliberalisation}

The proposal for staging Formula E in Battersea Park was initially rejected by Council leaders, a decision that was overturned when race organisers came back with a much bigger offer (Interview with WBC; Interview with Enable L\&C). This suggests that financial motives underpinned this controversial initiative. The philosophy of the Council was evident in one justification cited for the event "we've got a very clear duty to our residents to maximise the value of our assets" (Interview with WBC). Wandsworth Council negotiated a lucrative deal with Formula $\mathrm{E}$ which meant that they received $£ 1$ millon for each weekend of racing, plus compensation for the races in 2017-2019 that had been cancelled (c. $£ 2.8$ million in total). WBC insisted that money was not the only motivation for staging the races, and claimed they would have gone ahead even if the sums involved were much lower: "I think we still would have done it because it was a great event. Sixty thousand people went to it, 15,000 from our Borough. That was a great success. We were very chuffed to be hosting it" (Interview with WBC). Echoing justifications for previous incursions, officials also thought that the events would attract different sorts of people to visit the Park. 
A recurring criticism of the Formula E project was that it demonstrated how WBC used Battersea Park as a 'cash cow'. The Council rejected this interpretation: "We reckon it costs us about $£ 3.2 / 3.3$ million a year to run the park. And we take in in revenues of $£ 3.5$ million. So, that clearly shows it's not a very big cash cow" (Interview with WBC). Nevertheless, these figures confirm that Battersea Park is not only financially self-sufficient, but profitmaking. WBC felt they were relatively restrained when it came to maximising the commercial value of the site: "We could raise an awful lot more from Battersea Park if we chose to run everything purely on a commercial basis". This view was challenged by other stakeholders interviewed, not surprisingly by the BPAG representative who made the link between the Council's low council tax rate (it has the second lowest rate in the UK) and its eagerness to stage lucrative events. One commercial event organiser felt that WBC is: "pretty ruthless and they're probably the extreme, probably their biggest drive is finance rather than other priorities" (Interview with CSM).

Various stakeholders noted the way councils are now relying on events to help generate revenue for parks, and most stakeholders accepted this as a pragmatic solution to the current funding crisis. The Parks for London representative supported the Battersea Park event:

“there's a market for it. And so, why not? Why not? Because the other income that they derive from their licences goes some way towards meeting their revenue cost but it's not enough. So a few short, sharp events help to make that bit of extra money".

The idea that park events are justified because 'there's a market for it', highlights the extent to which parks are now integrated within the market economy. There was also evidence that officials regarded restricted access to public amenities as a necessary "sacrifice" to enable 
place marketing and economic development. A representative from London and Partners (The Mayor of London's official promotional agency) justified ticketed events by arguing that people who want to live in "dynamic, successful cities" should "expect" that their parks will be used for events.

Most stakeholders advocated a 'balanced' and regulated approach which ensures that events do not take up a disproportionate amount of time or space (Interview with Parks Alliance; Interview with HLF), but some were more uncomfortable with park events. The Chair of the London Green Spaces Friends Network felt commercial events were "not a coherent, ethical, or sustainable strategy for the funding for green spaces". He pointed to examples where revenue earned has been used as an excuse to reduce public funding, and expressed concern about parks policy being driven by financial motives rather than people's needs.

In the era of self-financing parks one might expect the monies raised from commercial events to be used to help fund the park that hosted the event, but in parks managed by local authorities money tends to go back into Council budgets or to the parks service generally. As the Councillor involved in the Battersea Park / Formula E case put it: "we never get into hypothecating revenue to a particular place" (Interview with WBC). For the Formula E events, because the disruption was so extensive, some of the funds generated were allocated specifically to Battersea Park projects. This money (£500, 000) was combined with a $£ 250,000$ contribution from the developers of homes next to Battersea Park and money from Friends of Battersea Park to produce a fund of $£ 820,000$ for park improvements. This cocktail of funding - events, real estate and donations - is representative of the way 'entrepreneurial' parks are funded. 
The significance of commercial activities, particularly events, is changing the ways parks are managed and governed. This was highlighted by one of the HLF interviewees who noted that park managers now tend to know less about horticulture and are more likely to be "a commercial person, or an events or leisure-type person". A new entrepreneurial approach to park management also provides an incentive to set up trusts or social enterprises to manage parks outside of local authority control, allowing park organisations to ring-fence revenues they earn. During the critical period (2014-2016) when Formula E events were organised, responsibility for Battersea Park was contracted out to a newly created organisation (Enable Leisure \& Culture). The new agency, created to make parks provision in Wandsworth more efficient and less reliant on public sector funds, is staffed by parks and events professionals who used to work for the Council. This is a deliberately engineered coalition of expertise that allows the events potential of park spaces to be optimised (Interview with Enable L\&C). The organisation is a not-for-profit, but has ambitious revenue generating targets and its mutual status means staff benefit from additional revenue earned. BPAG feel the agency provides an incentive "to get as many of these events into the park as possible" (Interview with BPAG). The creation of Enable L \& C represents an entrepreneurial push for more event revenues, but the fact it has responsibility for all parks in Wandsworth, not just Battersea Park, means one problematic characteristic of neoliberal parks - the way that commercialisation benefits some parks at the expense of others - is avoided.

Whatever governance arrangements are in place, permission from the local authority is usually required to stage large-scale events in parks and this does provide a degree of democratic accountability. Every time proposals to stage the Formula E races were considered by WBC, they were voted through by a majority of elected councillors. Nevertheless, sceptics question a process in which politicians and planning officers decide on 
the merits of proposals which will net local authorities millions of pounds. In the case of Wandsworth Council's scrutiny of the Formula E project, WBC insisted that this was not an issue as "the councillors who sit on the Planning Committee are highly independent". However, the impartiality of Councillors was questioned during the process which ratified the Formula E races. The BPAG objected to the way that (for a short time in 2015) proposals were scrutinised by a Committee whose Chair was also a Director of Enable (Interview with BPAG).

Democratic accountability in parks management is also reduced in entrepreneurial parks through the revised way parks are funded. When parks are self-financing, then local people become merely park users rather than stakeholders. This makes it harder for local residents to oppose significant projects like the Formula E races. Disenfranchisement is even more of an issue in Boroughs like Wandsworth where Council Tax returns represent only a small proportion (14\%) of the local authority's income. This makes it easier to dismiss local opposition such as the campaign by the BPAG: "One argument that, initially, a lot of the protesters put forward was, well, we pay our council tax. Therefore, we've got a right to be left alone" ... "they were using that same argument that paying council tax and living nearby makes it their park. Well, I'm sorry. It isn't" (Interview with WBC). According to the Council, living near the Park does not mean you have any more rights than anyone else - it is for all of the Borough's residents and, because National Lottery Funding was used to the restore the Park, "It's the nation's park in that sense" (Interview with WBC). The combination of commercial funding and grants from national organisations has helped to maintain and improve the park, but it distances the park from its local users by diminishing their stake in it. Alternative funding streams reinforce the image of Battersea Park as a destination, rather than 
a local amenity, and these contrasting interpretations of what the Park is - and who it is for help to explain why conflicts such as the one over Formula E arise.

\section{Discussion}

The research here highlights that the commercialisation of Battersea Park is not just a contemporary phenomenon. The Pleasure Gardens installed to accompany the 1951 Festival of Britain mean the distinction here between theme park and public park has long been blurred. Since the Conservative -led local authority assumed responsibility for the park in 1986, commercialisation has intensified, driven by the stated intention to capitalise on the financial value of Battersea Park. This has been orchestrated by a local authority, Wandsworth Council who have pursued a subtle yet significant form of marketisation and privatisation: staging commercial events. Ticketed events generate large amounts of revenue, and are easier to justify than permanent, physical incursions. Events are justified as merely temporary occasions that provide entertainment for residents and attract different users but they restrict the availability of park space and provide precedents for future commercialisation. Ticketed events allow the market value of park space to be realised, and they provide a vehicle through which parks are promoted as destinations. Competing for events, and competing through events, integrates parks into the market economy; reimagining them as commercial spaces.

Battersea Park has also been commercialised by events in a more obvious, physical way. The 1951 Festival of Britain provided the justification to develop a large part of the Park into a commercial visitor attraction. The changes made were initially justified as temporary installations, but they remained for decades after. The Pleasure Gardens left large sites that 
have been subsequently built on, most notably the British Genius Site which hosts a semipermanent corporate events venue. Temporary projects are often advocated as a strategy for encouraging development in brownfield sites (Bishop and Williams, 2012) but this case emphasises that time limited projects can also act as precursors to the development of urban green space.

A recurring debate in Battersea Park's evolution is the balance between the provision of open space and 'entertainment'. This has predominantly been debated as a spatial issue - what proportion of open space should be dedicated to recreational facilities? But the increasing number of events staged in the Park means this is now a temporal one too - how much park time should events be allowed to take up? Whilst installing paid for attractions constitutes the commercialisation of park space, events involve the commercialisation of park time. People are unwilling to pay to use public parks (Interview with HLF), and will not tolerate them being sold off (Perkins, 2009), therefore events provide a way of imposing payments and restricting access that is more socially acceptable. There are important links here to Boykoff's (2013, p.5) work on celebration capitalism, the "affable cousin of disaster capitalism", in which the events context allows "plucky politicos and their corporate cohorts" to push through controversial policies.

In Wandsworth, events provided a key incentive to create a new parks organisation that is staffed and structured to capitalise on events, and retain the revenues earned. This has replaced conventional local authority management; further eroding the stake local taxpayers have in their Park. Staging large scale events also represents a way to disrupt conventional practice. Stakeholders interviewed recognised that Formula E was an extreme project, and one for which conventional rules and norms were dismantled: 
"It's pushed the boundaries of what we can do in a park. It's pushed the boundaries in terms of what we can legally do and what we can't do, and I'm not out to break down the boundaries or the legal framework, but it's making people look afresh of what is permissible, what is acceptable" (Interview with Parks for London).

It is easy to dismiss the Formula E races as merely time limited interventions that caused temporary impacts, but staging these events pushed the boundaries of what is appropriate for a public park. This suggests a more enduring legacy: the long term effects of the Festival of Britain Pleasure Gardens reminds us that once 'exceptional' events are permitted, they can provide a foundation for other commercial events and more permanent developments in parks. Formula E acknowledged explicitly that their races in Battersea Park might represent "the thin end of the wedge":

"if councils are allowing major events like that to happen in parks because they're using the argument we need the income as a council, .... it opens the door to anybody coming in and where does it stop, where does it stop? And that's what they're worried about and I can see that" (Interview with Formula E).

It is no coincidence that these extreme forms of commercialisation are being adopted at a time when local governments are facing large cuts. This has prompted a public parks 'crisis' in the UK - rhetoric which justifies radical interventions and further commercialisation. Jessop and Oosterlynck (2008) describe such crises as 'path shaping moments' and it is not difficult to find examples of these moments in parks history. The fiscal retrenchment of the 1970s ushered in changes to New York's parks (Osman, 2016), including new funding 
arrangements based on their development capacities for real estate and commercial activity (Krinsky and Simonet, 2011). In a similar vein, the period of austerity implemented by the government post-2010 is reshaping UK parks as more commercially oriented spaces, with ticketed events normalising the part-privatisation of park space by limiting public access to large areas.

According to Lowes (2002) there is a dearth of detailed analysis of successful opposition to neoliberal event projects and, by exploring the Formula E case, this study has helped to address this deficiency. Persistent campaigning by BPAG prevented further Formula E races beyond 2016. The Group have pressurised Wandsworth Council to restore Battersea Park to its pre-2015 state; and aim to protect the Park in the future (Interview with BPAG). Other unpopular forms of commercialisation in the latter half of the $20^{\text {th }}$ century were successfully opposed too. But even failed projects can lay the foundations for future incursions, and the threat of further commercialisation continues to hang over Battersea Park.

The processes and conflicts discussed here seem to typify those associated with urban neoliberalism, where the state encourages the expansion of the scope and reach of capital (Peck and Tickell, 2002). As Schweinsberg et al. (2017, p.249) suggest: "many urban spaces including parks are under pressure to provide economic value to the city as part of broader neoliberal planning agendas”. However, closer scrutiny suggests that equating park commercialisation with urban neoliberalisation might be an oversimplification. The historical review presented here suggests that event driven commercialisation is an established feature of parks, rather than one confined to the neoliberal era. Applying the specific definitions of park neoliberalisation discussed in the early stages of this paper is awkward too. For Millington (2015) and Krinsky and Simonet (2011), park neoliberalisation represents the 
neglect of green spaces in poorer areas because parks in richer zones are better positioned to generate their own revenue. But in Wandsworth a governance model was adopted where revenues generated are shared amongst all the Borough's parks - a more redistributive and benevolent model. Some of the broader limitations of neoliberalisation as an analytical or descriptive tool are also exposed. The case analysed here was not one which exemplified the 'all-encompassing power of neoliberalism' as an unstoppable tidal wave that diminishes local leadership (Newman, 2014, p.3302). In Wandsworth, the local authority has consistently and actively pursued a strategy of park commercialisation - for political and ideological reasons rather than being overwhelmed by forces beyond its control. Therefore, it is perhaps best to consider the processes marked here as a variant of neoliberalisation - one where the local state pulls down elements of neoliberal policy and articulates these with local programmes and projects Newman (2014). As Perkins (2010) notes, to understand the link between neoliberalism and reduced parks funding we have to consider power dynamics at, and between, the local and national levels.

\section{Conclusions}

This paper has highlighted the role events play in park commercialisation, by identifying the way they monetise park space and time, their role in promoting parks as venues/destinations and their influence on parks governance. The case study demonstrates that understanding park commercialisation requires recognition of the significance of ticketed events and their contestation; and it requires analysis that extends beyond contemporary examples into previous eras. Battersea Park is a case study that should interest leisure scholars: because of its fascinating past; and because of recent management that aims to commercialise and monetise this public 'asset', whilst stopping short of selling off parkland. Ticketed events are 
particularly useful tools for park authorities in this context - they comprise a form of temporary privatisation, and one that can be justified via reference to wider parks policy e.g. diversifying uses / uses. However, the case study here - and related disputes in London over music festivals staged in parks - also highlights that ticketed events are highly contested enclosures of public space.

Contested park events exemplify the intense competition between residents, capital and state for urban space. These conflicts are underpinned by the presence of interests that value public spaces differently: in terms of their exchange value or use value. As Lang and Rothenberg $(2016,16)$ argue, "striving to create green public spaces that reflect use values over exchange values is an uphill battle given the structural constraints and imperatives of neoliberal urbanism". The Battersea Park case suggests this has long been difficult, but it also highlights a new period of commercialisation in an era of neoliberal austerity (post 2010) in which the prioritisation of exchange value is now official policy, rather than merely implicit philosophy. More research is now needed to understand whether the ideas associated with neoliberal urbanism are the most useful ways to explore this commercial imperative; and how the rise of public-private parks differs from other forms of urban neoliberalisation.

\section{References}

Bianchini, F. (1987). GLC-RIP: Cultural policies in London 1981-1986. New

Formations, 1(1), 103-17.

Bishop, P. \& Williams, L. (2012). The Temporary City. London: Routledge. 
Boykoff, J. (2013). Celebration Capitalism and the Olympic Games. Abingdon: Routledge.

Bull, S. (1966) Battersea Park. Letter to The Times, 25 ${ }^{\text {th }}$ February 1966.

Chadwick, G. (1966). The park and the town: Public landscapes in the nineteenth and twentieth centuries. New York: FA Praeger.

Comedia/Demos (1995). Park Life: Urban Parks and Social Renewal. May 1995.

Cooke, O. (2007). A class approach to municipal privatization: the privatization of New York City's Central Park. International Labor and Working-Class History, 71(01), 112-132.

Davidson, M. (2013). The sustainable and entrepreneurial park? Contradictions and persistent antagonisms at Sydney's Olympic Park. Urban Geography, 34(5), 657-676.

De Magalhaes, C. \& Carmona, M. (2009). Dimensions and models of contemporary public space management in England. Journal of Environmental Planning and Management, 52(1), 111-129.

De Magalhães, C. \& Freire Trigo. (2016). Contracting out publicness: The private management of the urban public realm and its implications. Progress in Planning (in press)

Elborough, T. (2016) A Walk in the Park. The Life and Times of a People's Institution. London: Random House. 
Harding, S. (1999). Towards a renaissance in urban parks. Cultural Trends, 9(35), 1-20.

Jessop B. \& Oosterlynck, S. (2008) Cultural political economy: On making the cultural turn without falling into soft economic sociology. Geoforum, 39(3): 1155-1169.

Krinsky, J. \& Simonet, M. (2011). Safeguarding private value in public spaces: the neoliberalization of public service work in New York City's Parks. Social Justice, 38(1/2 (123-124), 28-47.

Lang, S. \& Rothenberg, J. (2017). Neoliberal urbanism, public space, and the greening of the growth machine: New York City's High Line park. Environment and Planning A (in press).

Lasdun, S. (1991). The English Park: Royal, Private \& Public. New York: Vendome Press.

Loughran, K. (2014). Parks for profit: The high line, growth machines, and the uneven development of urban public spaces. City \& Community, 13(1), 49-68.

Lowes, M. (2002). Indy Dreams and Urban Nightmares: Speed Merchants, Spectacle, and the Struggle over Public Space in the World-Class City. Toronto: University of Toronto Press.

Madden, D. (2010). Revisiting the end of public space: assembling the public in an urban park. City \& Community, 9(2), 187-207. 
McInroy, N. (2000). Urban regeneration and public space: the story of an urban park. Space and Polity, 4(1), 23-40.

Millington, N. (2015). From urban scar to 'park in the sky': terrain vague, urban design, and the remaking of New York City's High Line Park. Environment and Planning A, 47(11), 2324-2338.

Mitchell, J. (2003). Festival Pleasure Gardens and after. In: Friends of Battersea Park (Eds.) Battersea Park: an Illustrated History (pp.67-84). London: Friends of Battersea Park.

Nevarez, J. (2007). Central Park: The aesthetics of urban order. In Karen Franck \& Quentin Stevens (Eds.) Loose Space: Possibility and Diversity in Urban Life (pp.154-170). Abingdon: Routledge.

Nice, S. (1983). A masterplan for the rejuvenation of Battersea Park. Landscape Research, 8(2), 16-18.

Osman, S. (2017). "We're doing it ourselves" the unexpected origins of New York City's public-private parks during the 1970s Fiscal Crisis. Journal of Planning History, 16(2), 162174.

Peck, J., \& Tickell, A. (2002). Neoliberalizing space. Antipode, 34(3), 380-404.

Perkins, H. (2009). Turning feral spaces into trendy places: a coffee house in every park? Environment and Planning A, 41(11), 2615-2632. 
Perkins, H. (2010). Green spaces of self-interest within shared urban governance. Geography Compass, 4(3), 255-268.

Rosol, M. (2010). Public participation in post-Fordist urban green space governance: The case of community gardens in Berlin. International Journal of Urban and Regional Research, 34(3), 548-563.

Schweinsberg S., Darcy S. \& Cheng, M. (2017). The agenda setting power of news media in framing the future role of tourism in protected areas. Tourism Management, 62: 241-252.

Smith, A. (2014). 'Borrowing' public space to stage major events: The Greenwich Park controversy. Urban Studies, 51(2), 247-263.

Smith, A. (2016). Events in the City: Using Public Spaces as Event Venues. Abingdon: Routledge.

Smith, H., Dempsey, N. and Burton, M. (2014). Coordinating place-keeping : towards more sustainable places. In Nicola Dempsey, Harry Smith \& Mel Burton (Eds.) Place-Keeping: Open Space Management in Practice (pp.173-194). New York: Routledge.

South London Press (1976). Action group protest against $£ 1 \mathrm{~m}$ exhibition. $13^{\text {th }}$ August 1976.

South London Press (1980). Who will develop Battersea Park? 22 ${ }^{\text {nd }}$ February 1980. 
Tranter, P. \& Lowes, M. (2009). Life in the fast lane. Environmental, economic and public health outcomes of motorsport spectacles in Australia. Journal of Sport and Social Issues, 33(2), 150-168.

Turner, B. (2011). Beacon for Change: How the 1951 Festival of Britain Shaped the Modern Age. London: Aurum Press Limited.

Wandsworth Borough Council (2003). Report by the Director of Leisure and Amenity Services on an updating of the Events Strategy for Battersea Park, SW11 (Queenstown).

Wandsworth Borough Council (2014). Planning Application 2014/6976.

Wandsworth Borough Council (2017). Planning Application 2017/0937.

Wandsworth Borough News (1991a). Opposition to Imax Cinema in Park. Wandsworth Borough News $18^{\text {th }}$ October 1991.

Wandsworth Borough News (1991b). Preserving the Patchwork. Wandsworth Borough News Nov 8th 1991.

Wandsworth Borough News (1998). Anger mounts over park use. Wandsworth Borough News $28^{\text {th }}$ November 1998.

Wandsworth Borough News (1999). Parks' record profit. Wandsworth Borough News $16^{\text {th }}$ April 1999. 
Wandsworth Borough News (2001) Events for park spark complaint. Wandsworth Borough News $27^{\text {th }}$ February 2001.

Zukin, S. (1995). The Cultures of Cities. Oxford: Blackwell.

Zukin, S. (2010). Naked City. The Death and Life of Authentic Urban Places. Oxford: Oxford University Press. 